\title{
The contribution of propionate to glucose synthesis in sheep given diets of different grain content
}

\author{
BY G. J. JUDSON, ELIZABETH ANDERSON, J. R. LUICK* \\ AND R. A. LENG \\ Department of Biochemistry and Nutrition, School of Rural Science, \\ University of New England, Armidale, NSW 235 I, Australia
}

$$
\text { (Received I9 April, 1967-Accepted I8 fuly 1967) }
$$

\footnotetext{
1. Glucose entry rates into the blood and propionate production rates in the rumen have been measured in sheep given rations containing varying proportions of starch and roughage (lucerne).

2. Glucose entry rates and propionate production rates were similar for all rations studied.

3. The proportion of the glucose entry rate arising from propionate produced in the rumen was highest on the ration containing the greatest quantity of lucerne and decreased as the proportion of starch in the ration increased. Rate of conversion of propionate into glucose was estimated and was found to decrease as the amount of starch in the ration increased.

4. Concentrations of total volatile fatty acids (VFA) in the ruminal fluid were lowest in the ration with the greatest proportion of starch, implying lower VFA production rates with the starch rations although intakes of digestible energy were approximately the same. The mean concentrations and rates of production of propionate in ruminal fluid were similar for all rations.

5. The low VFA concentrations and the reduced conversion of propionate into glucose on the high rations, despite similar propionate production rates and glucose entry rates, may have been due to starch escaping ruminal fermentation. It is suggested that this glucose absorption may have reduced gluconeogenesis from propionate.
}

In ruminants, gluconeogenesis is a major biosynthetic process, since apparently only in animals given a high proportion of starch in their diets could there be significant absorption of glucose from the alimentary tract (MacRae \& Armstrong, x966; Lindsay, 1959; Armstrong, 1965). Estimates of glucose entry rates in non-pregnant sheep have varied from $\mathrm{I} \cdot 4$ to $4.3 \mathrm{mg} / \mathrm{kg}$ per min (Annison \& White, $196 \mathrm{I}$; Kronfeld \& Simesen, I961; Bergman, I963; Ford, 1963, I965; Bergman, Roe \& Kon, I966; Leng, Steel \& Luick, 1967 ). The variations in estimates may be in part attributed to differences in the feeding regime and in the techniques adopted in the various laboratories. For instance, in most studies animals were fed once or twice daily and entry rates were estimated some time after the animal had eaten; this usually coincided with maximum volatile fatty acid (VFA) concentration in the rumen. Ford (1965) has shown that glucose entry rate in sheep varied with the quantity and quality of food eaten and he suggested that there was an increase in gluconeogenesis as feed intake increased.

In sheep given lucerne at hourly intervals, propionate produced in the rumen contributed $54 \%$ of the carbon of the glucose synthesized (Leng et al. 1967), whereas it was shown by Bergman et al. (I966) that absorbed propionate contributed $27 \%$ of the glucose entry rate. As only a relatively small proportion of the propionate produced in the rumen was converted into glucose, it appeared that on the diets of lucerne

* Present address: Department of Arctic Biology, University of Alaska, Alaska, USA. 
there are more glucose precursors absorbed from the alimentary tract than are required (Bergman et al. 1966; Leng et al. 1967). Because diet has a great effect on production of glucose precursors in the rumen and small intestine of sheep (i.e. propionate and amino acids) and since glucose may be absorbed as such on diets high in grain, the effects of the proportion of starch to roughage in a diet on glucose entry rates and the contribution of propionate to glucose have been investigated.

\section{EXPERIMENTAL}

Animals. Eighteen Merino wethers, aged 3 years, were held in metabolism cages. Each sheep had a rumen cannula fitted at least 8 weeks before the investigations. Groups of six sheep were each given one of the following rations which maintained their weight over the experimental period: ration A, $400 \mathrm{~g}$ crushed maize; ration $\mathrm{B}$, $250 \mathrm{~g}$ lucerne, $260 \mathrm{~g}$ crushed maize; ration $\mathrm{C}, 400 \mathrm{~g}$ lucerne, $200 \mathrm{~g}$ crushed maize. For 8 weeks before these investigations the rations were given daily at $08.00 \mathrm{~h}$. For the 6 days preceding each experiment the sheep were given their ration in twelve equal amounts at hourly intervals from $07.00 \mathrm{~h}$ to $18.00 \mathrm{~h}$. On the 5 th day of this regime the animals were infused intraruminally with $\left[2-{ }^{14} \mathrm{C}\right]$ propionate and on the 6 th day [U- $\left.{ }^{14} \mathrm{C}\right] g l u c o s e$ infusions were made intravenously. Blood samples taken before infusion on the 6th day indicated negligible residual activity in circulating glucose. For each substrate infused, only four animals were used from each group.

Measurement of glucose entry rate into plasma and propionate production rate in the rumen. $\left[2-{ }^{14} \mathrm{C}\right]$ Propionate was infused into the rumen and $\left[\mathrm{U}_{-}{ }^{14} \mathrm{C}\right] \mathrm{glucose}$ was infused intravenously by the methods reported by Leng \& Leonard (1965) and Leng $e t$ al. (1967). The infusions were timed so that the measurements of production rate of propionate, entry rate of glucose and conversion of propionate into glucose were made when the VFA concentrations in the rumen had reached a plateau (Leng \& Leonard, 1965). Conversion rate of propionate into glucose was calculated by the method of Leng et al. (1967).

Chemical methods. Techniques for the estimation of VFA, isolation of propionate and determination of specific radioactivity of propionate have been described by Leng $\&$ Leonard ( 1965 ). Plasma glucose concentrations were determined by the method of Huggett \& Nixon (1957) and glucose was isolated and assayed for radioactivity as the penta-acetate derivative (Jones, 1965).

Radioactive compounds. Sodium $\left[2-{ }^{14} \mathrm{C}\right]$ propionate and $\left[\mathrm{U}-{ }^{14} \mathrm{C}\right] \mathrm{D}$-glucose were purchased from the Radiochemical Centre, Amersham, England. Infusion solutions containing propionate were assayed for radioactivity after the addition of carrier propionate (Leng \& Leonard, 1965). Infusates containing [U-14 $\mathrm{C}]$ glucose were assayed by adding glucose carrier ( $100 \mathrm{mg}$ ) to $\mathrm{I} \mathrm{ml}$ of infusate and isolating the glucose as its penta-acetate derivative (Jones, 1965).

\section{RESULTS}

Glucose entry rates. Glucose entry rates are shown in Table $\mathrm{r}$. Plasma glucose concentrations remained approximately constant throughout the experimental period and 
the glucose specific radioactivity reached a plateau between 3 and $6 \mathrm{~h}$ after the start of each infusion. In all experiments the variations in concentrations and specific radioactivities were similar to those reported previously (Leng et al. r967). The mean glucose entry rates (excluding two results where animals did not eat) were not significantly different on the three rations.

Table I. Glucose entry rates in sheep given different rations (see p. 70) and intravenous infusions of $\left[U_{-14} C\right]$ glucose infused at a rate of between 0.05 and $0.09 \mu \mathrm{c} / \mathrm{min}$

\begin{tabular}{|c|c|c|c|c|c|c|}
\hline \multirow[b]{2}{*}{$\begin{array}{c}\text { Sheep } \\
\text { no. }\end{array}$} & \multirow[b]{2}{*}{$\begin{array}{l}\text { Sheep } \\
\text { wt (kg) }\end{array}$} & \multirow[b]{2}{*}{ Ration } & \multirow{2}{*}{$\begin{array}{c}\text { Mean } \\
\text { plasma } \\
\text { glucose } \\
(\mathrm{mg} / \mathrm{ro0} \mathrm{ml})^{*}\end{array}$} & \multicolumn{3}{|c|}{ Glucose entry rate } \\
\hline & & & & $\mathrm{mg} / \mathrm{min}$ & $\mathrm{m}$-moles/min & $\mathrm{mg} / \mathrm{kg} \min$ \\
\hline 167 & 33 & A & $8 \mathrm{I} \cdot \mathrm{I}$ & $41 \cdot 6$ & 0.23 & $I \cdot 26$ \\
\hline 89 & 29 & A & $68 \cdot 3$ & $36 \cdot 6$ & 0.20 & $1 \cdot 26 \dagger$ \\
\hline 320 & 38 & A & $89 \cdot 6$ & $70 \cdot 5$ & 0.39 & $I \cdot 86$ \\
\hline 34 & 28 & A & $74 \cdot 5$ & $49^{\circ} \mathrm{I}$ & 0.27 & $x \cdot 76$ \\
\hline 37 & 34 & B & $89 \cdot 6$ & $69^{-6}$ & 0.39 & 2.05 \\
\hline 68 & $3^{8}$ & B & $58 \cdot 5$ & $58 \cdot x$ & 0.32 & $\mathrm{x} \cdot 53$ \\
\hline I74 & 29 & B & $87 \cdot 4$ & $75 \cdot 2$ & 0.42 & $2 \cdot 59$ \\
\hline 329 & $4 \mathrm{I}$ & B & $69 \cdot 6$ & $56 \cdot 8$ & 0.32 & $I \cdot 38$ \\
\hline 6 & 34 & $\mathrm{C}$ & $62 \cdot 7$ & $4 I \cdot 0$ & 0.23 & $I \cdot 2 I+$ \\
\hline 147 & 36 & C & $72 \cdot 2$ & $49 \cdot 2$ & 0.27 & $I \cdot 37$ \\
\hline 123 & 30 & C & $70 \cdot 9$ & $6 I \cdot 0$ & 0.34 & $2 \cdot 03$ \\
\hline 182 & 32 & C & $6 I \cdot 2$ & $66 \cdot 4$ & 0.37 & $2 \cdot 08$ \\
\hline
\end{tabular}

Table 2. Concentration (m-moles/l. rumen liquor) of total volatile fatty acids in the rumen of sheep given different rations (see p. 70), and the proportions of individual VFA expressed as molar percentages of total VFA

\begin{tabular}{|c|c|c|c|c|c|c|c|c|}
\hline \multirow[b]{2}{*}{$\begin{array}{c}\text { Sheep } \\
\text { no. }\end{array}$} & \multirow[b]{2}{*}{ Ration } & \multirow{2}{*}{$\begin{array}{c}\text { Total } \\
\text { VFA } \\
\text { concen- } \\
\text { tration } \\
\text { (m-moles/1.) }\end{array}$} & \multicolumn{6}{|c|}{ Molar percentage of VFA as } \\
\hline & & & $\begin{array}{l}\text { Acetic } \\
\text { acid }\end{array}$ & $\begin{array}{l}\text { Propionic } \\
\text { acid }\end{array}$ & $\begin{array}{l}\text { Butyric } \\
\text { acid }\end{array}$ & $\begin{array}{c}\text { Isobutyric } \\
\text { acid }\end{array}$ & $\begin{array}{l}\text { Isovaleric } \\
\text { acid }\end{array}$ & $\begin{array}{l}\text { Valeric } \\
\text { acid }\end{array}$ \\
\hline 167 & A & $69+1$ & - & 一 & - & - & - & - \\
\hline 89 & A & $60 \cdot 6$ & $52 \cdot 5$ & $39^{\cdot} 8$ & $3 \cdot 9$ & $1 \cdot 5$ & $1 \cdot 4$ & 0.9 \\
\hline 329 & A & $63 \cdot 3$ & $49 \cdot 2$ & $38 \cdot 9$ & $9 \cdot I$ & 1.0 & $I \cdot I$ & 0.8 \\
\hline 34 & A & $64 \cdot 4$ & $52 \cdot 2$ & $39^{\circ} 5$ & $5 \cdot 0$ & $\mathbf{r} \cdot \mathbf{3}$ & 0.7 & $I \cdot 2$ \\
\hline $\begin{array}{l}37 \\
68\end{array}$ & $\begin{array}{l}\mathrm{B} \\
\mathrm{B}\end{array}$ & $\begin{array}{l}71 \cdot 1 \\
62 \cdot 2\end{array}$ & $\begin{array}{l}63 \cdot 3 \\
61 \cdot 5\end{array}$ & $\begin{array}{l}19.5 \\
18.6\end{array}$ & $\begin{array}{l}12.4 \\
13.8\end{array}$ & $\begin{array}{l}1 \cdot 5 \\
1 \cdot 6\end{array}$ & $\begin{array}{l}1 \cdot 5 \\
2 \cdot 5\end{array}$ & $\begin{array}{l}I \cdot 7 \\
1 \cdot 9\end{array}$ \\
\hline 16 & B & 87.0 & $63 \cdot 6$ & $21 \cdot 5$ & 11.3 & $1 \cdot 3$ & 0.8 & $1 \cdot 4$ \\
\hline 174 & B & $82 \cdot 7$ & $6 x \cdot 6$ & $24 \cdot 8$ & $10 \cdot 3$ & 1.0 & $\mathbf{I} \cdot \mathbf{I}$ & $\mathbf{I} \cdot \mathbf{2}$ \\
\hline 6 & $\mathrm{C}$ & $109 \cdot 4$ & $65 \cdot 1$ & $15 \cdot 8$ & 13.6 & $1 \cdot 3$ & $2 \cdot 2$ & 2.0 \\
\hline 147 & C & 129.0 & $61 \cdot 5$ & $21 \cdot 9$ & I $1 \cdot 4$ & $1 \cdot 3$ & I. 8 & $2 \cdot 1$ \\
\hline 119 & C & $93 \cdot \mathbf{I}$ & 66.0 & $22 \cdot 0$ & $9 \cdot 3$ & $I \cdot 2$ & 0.6 & 0.9 \\
\hline 27 & C & 107.5 & $61 \cdot 5$ & $2 \mathrm{I} \cdot 3$ & r.I & $1 \cdot 0$ & $1 \cdot 3$ & $1 \cdot 9$ \\
\hline
\end{tabular}

Effects of diet on the concentrations and molar proportions of VFA in the rumen. VFA concentrations in ruminal fluid were highest in the animals consuming the greatest quantity of lucerne (Table 2); as the amount of starch in the ration increased the total 


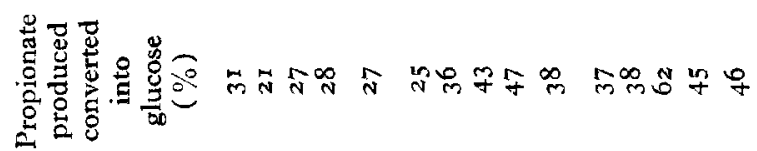

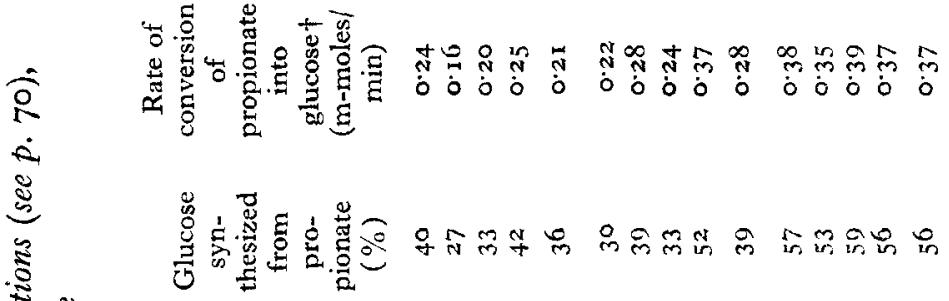

$\stackrel{8}{3}$

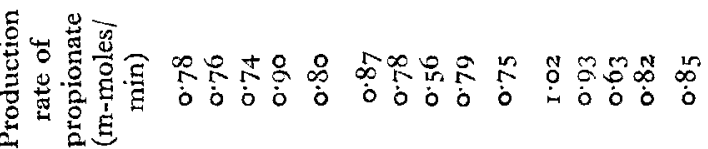

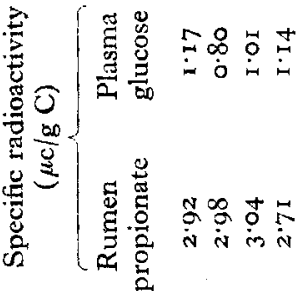

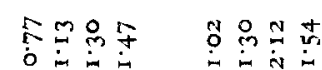

के के

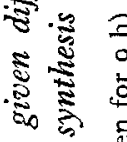

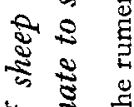

के.

है है

3

त

.

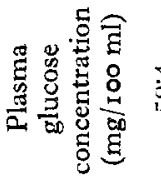

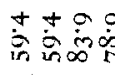

indo

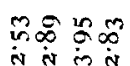

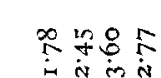

\section{(1)}

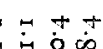

त $\mathrm{Am}$

का कित

穿密

$\dot{m}$

营

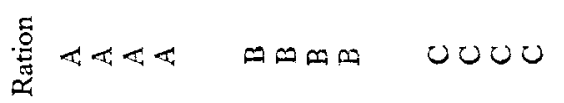

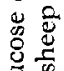

岁

क力 马ु

Е

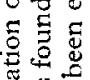

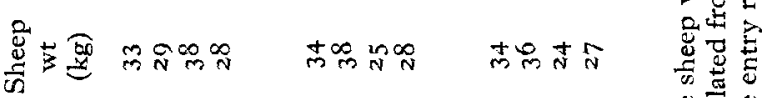

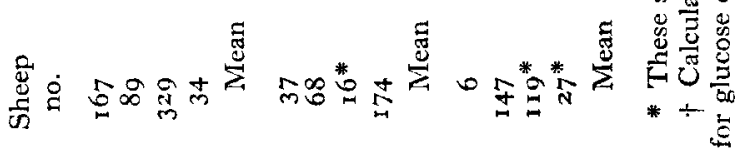


VFA concentration decreased, but the proportion of propionate increased. As a result, the actual concentration of propionate was not markedly altered.

Propionate production rates in the rumen and the conversion of propionate into glucose. The mean production rates of propionate on the three rations were similar (Table 3 ). The proportion of the glucose entering the body pool that was derived from propionate, the net conversion rate of propionate into glucose and the percentage of the propionate produced in the rumen which was converted into glucose increased as the proportion of lucerne in the ration increased.

\section{DISCUSSION}

The glucose required by sheep to meet the demands for biosynthetic processes and for oxidation in specific organs cannot be estimated by the techniques used here since, in sheep, glucose entry rate and requirements for glucose are not necessarily the same. However, the glucose requirements of sheep may approximate to the quantity synthesized on an all-roughage diet where little, if any, glucose is absorbed from the alimentary tract. The need for gluconeogenesis in sheep is variable and depends on the absorption of glucose from the intestinal tract and the requirements of the animal for glucose. Absorption of glucose from the intestinal tract in substantial quantities may reduce the necessity for gluconeogenesis, since the production of glucose from shortchain intermediates in excess of requirements is an energy-requiring process. In pregnancy and lactation, when the requirements for glucose are probably increased, the animal has to increase the synthesis of glucose from short-chain intermediates. That is, the sheep must adapt to physiological circumstances and there must be a controlling mechanism regulating the rate of gluconeogenesis (Krebs, I964). In normal sheep given roughage diets or grazing there seems to be little reason to suppose that there will be a shortage of glucose precursors, since considerably more propionate is produced in the rumen than is apparently required for glucose production (Leng $\&$ Leonard, I965; Bergman, Reid, Murray, Brockway \& Whitelaw, I965; Leng, Corbett $\&$ Brett, I968). However, Ford (1965) found that glucose entry rates in sheep were two to three times greater on freshly cut spring grass than on a diet of hay and oats. This was attributed to a higher intake of protein on the spring grass diet; it is not known how much glucose is absorbed from the intestines of sheep given these diets. The apparent increase in glucose synthesis at high levels of intake, especially where animals are fattening, may be due to the demand for glycerol for triglyceride synthesis. However, it has not been determined whether all glycerol synthesis occurs from glucose or whether some glycerol is synthesized directly from propionate. Adipose tissue synthesizes glyceride glycerol from glucose since there is apparently no glycerol kinase present in this tissue (Shapiro, Chowers \& Rose, r957; Cahill, Leboeuf \& Renold, 1960; Lynn, MacLeod \& Brown, 1960). However, the quantitative requirements for glycerol on these diets are not known.

The rate of fat deposition will depend on the ration given and also on the previous nutritional history of the animal. A sheep changing from a low to a high plane of nutrition may require more glucose as there may be an increased requirement for 
glycerol for fat deposition and of glucose for the synthesis of compounds such as glycolipids, nucleic acids and mucopolysaccharides. When studying glucose synthesis in animals a steady rate of glucose synthesis is desirable throughout an experimental period and is conveniently achieved by continuous feeding since in animals fed once daily glucose entry rates may be continuously changing.

Mean entry rates of glucose on all rations (excluding results when animals were not eating) were not significantly different, but the variation within each group was much greater than the variation of other results published from this laboratory (Leng $e t a l$. 1967).

The concentrations of VFA and their molar proportions were similar between sheep on the sameration. The proportion of propionate was highest on the high-starch rations but the concentrations of propionate and the production rates of propionate in the rumen were similar in all sheep, demonstrating that the molar proportions of the acids in the rumen are not necessarily indicative of relative production rates of these acids.

The significant trends in the percentage of the glucose produced from propionate, and the percentage of the propionate converted into glucose, indicate that on the highstarch rations there was less propionate being converted into glucose although the same amount of propionate was being produced. The lower concentrations of VFA in ruminal fluid on high-starch rations suggest that the actual production rates of VFA are lower than on the high-lucerne, low-maize rations since production and concentration of VFA are linearly correlated (Leng \& Brett, I966; Leng et al. 1968). A possible explanation for the reduction in glucose synthesis from propionate is that some of the starch was escaping fermentation in the rumen and was being absorbed as glucose. Support for this suggestion comes from the work of MacRae \& Armstrong (1966), who have shown that up to $22 \mathrm{~g}$ of glucose per day could be absorbed from the small intestine of sheep given grain-hay rations. Such an uptake of glucose from the alimentary tract in the present studies could have reduced gluconeogenesis from propionate and amino acids. The quantities of starch escaping fermentation could vary considerably between animals, and this may be the reason for the variable glucose entry rates reported here.

In non-ruminant animals such as the rat and dog it has been suggested that injection of exogenous glucose reduces glucose output by the liver (Soskin, Essex, Herrick \& Mann, 1938; Cahill, Ashmore, Earle \& Zottu, I958; Cahill, Ashmore, Renold \& Hastings, 1959; Landau, Leonards \& Barry, 1961; Searle \& Chaikoff, 1952; Reichard, Friedmann, Maass \& Weinhouse, I958), although this conclusion has been questioned by Steele (1959) and Steele, Bishop \& Levine (1959). Landau et al. (1961) have shown that, in dogs given high-carbohydrate diets, the liver responds to glucose infusion by ceasing to produce glucose and there is a net uptake of glucose by the liver such that the glucose concentration in plasma does not change. In sheep, Annison $\&$ White (196r) and West \& Passey (1967) have shown that an exogenous glucose load decreases endogenous glucose entry rate. It is possible, in those studies and the studies presented here, that the net glucose output by the liver was decreased and the quantity of glycogen stored increased. However, the glycogen reserves could not be expected to increase markedly. 
These investigations and previous studies from this laboratory now clearly indicate that well-fed, adult, non-pregnant sheep have an ample supply of glucose precursors.

We are indebted to the Australian Wool Research Committee, the Rural Credits Development Fund and the University of New England for financial support for this project.

\section{REFERENCES}

Annison, E. F, \& White, R. R. (196I). Biochem. F. 80, 162.

Armstrong, D. G. (1965). In Second International Symposium on the Physiology of Digestion in the Ruminant, Ames, Iowa, 1964, p. 272. [R. W. Dougherty, R. S. Allen, W. Burroughs, N. I. Jacobson and A. D. McGilliard, editors.] Washington, D.C.: Butterworth Inc.

Bergman, E. N. (rg63). Am. F. Physiol. 204, 147.

Bergman, E. N., Reid, R. S., Murray, M. G., Brockway, J. M. \& Whitelaw, F. G. (I965). Biochem. 7 . $97,53$.

Bergman, E. N., Roe, W. E. \& Kon, K. (1966). Am. F. Physiol. 21r, 793.

Cahill, G. F. Jr, Ashmore, J., Earle, A. S. \& Zottu, S. (1958). Am. F. Physiol. 192, 491.

Cahill, G. F. Jr, Ashmore, J., Renold, A. E. \& Hastings, A. B. (1 959). Am. F. Med. 26, 264.

Cahill, G. F. Jr, Leboeuf, B. \& Renold, A. E. (I960). Am. F. clin. Nutr. 8, 733.

Ford, E. J. H. (1963). Biochem. F. 88, 427.

Ford, E. J. H. (1965). F. agric. Sci., Camb. 65, 41.

Huggett, A. StG. \& Nixon, D. A. (1957). Biochem. J. 66, 12P.

Jones, G. B. (1965). Analyt. Biochem. 12, 249.

Krebs, H. (1964). Proc. R. Soc. B 159, 545.

Kronfeld, D. S. \& Simesen, M. G. (196r). Am. F. Physiol. 2or, 639.

Landau, B. R., Leonards, J. R. \& Barry, F. M. (I96r). Am. F. Physiol. 2or, 41.

Leng, R. A. \& Brett, D. J. (I966). Br. F. Nutr. 20, 541.

Leng, R. A., Corbett, J. L. \& Brett, D. J. (1968). Br. F. Nutr. 22, 57.

Leng, R. A. \& Leonard, G. J. (1965). Br. $\mathscr{f}$. Nutr. 19, 469.

Leng, R. A., Steel, J. W. \& Luick, J. R. (1967). Biochem. F. 103, 785 .

Lindsay, D. B. (1959). Vet. Rev. Annot. 5, 103.

Lynn, W. S., MacLeod, R. M. \& Brown, R. H. (I 960). \%. biol. Chem. 235, I904.

McRae, J. C. \& Armstrong, D. G. (1966). Proc. Nutr. Soc. 25, 33.

Reichard, G. A., Friedmann, B., Maass, A. R. \& Weinhouse, S. (1958). F. biol. Chem. $230,387$.

Searle, G. L. \& Chaikoff, I. L. (1952). Am. Y. Physiol. 170, 456.

Shapiro, B., Chowers, I. \& Rose, G. (1957). Biochim. biophys. Acta 23, II 5.

Soskin, S., Essex, H. E., Herrick, J. F. \& Mann, F. C. (1938). Am. F. Physiol. 124, $55^{8}$

Steele, R. (1959). Metabolism 8, 512.

Steele, R., Bishop, J. S. \& Levine, R. (1959). Am. F. Physiol. 197, 60.

West, C. E. \& Passey, R. F. (1967). Biochem. J. 102, 58. 